\title{
Quarrel over book leads to call for misconduct inquiry
}

Rex Dalton, San Diego

A political scientist and former journal editor has asked the US National Science Foundation (NSF) to set up an inquiry to determine whether scientific misconduct was involved in the writing of a psychological history book.

Gary Johnson, chair of the political science department at Lake Superior State University, Michigan, and former editor of the journal Politics and the

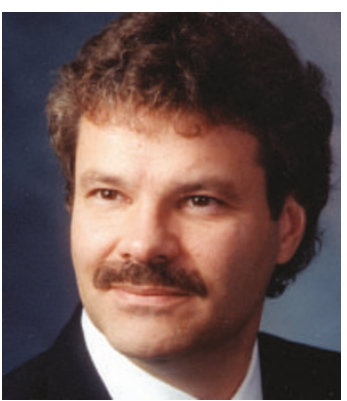

Gary Johnson requests review of data in birth-order book.
Lake Superior State's president at the time. Arbuckle says that he backs Johnson's actions as editor.

The complaint to the NSF inspector-general is based on the fact that Sulloway received a grant of about US\$120,000 from the agency in 1991 for research for the book, which also earned a $\$ 500,000$ advance from its publisher, Random House.

Sulloway was a visiting Life Sciences, wrote to the inspector-general's office at the NSF on 27 September, requesting a probe into the book Born to Rebel: Birth Order, Family Dynamics and Creative Lives by scientific historian Frank Sulloway.

In March this year, the journal published an edition almost entirely dedicated to criticism and commentary on the 1996 book, which argues that scientists and religious and political leaders who have older siblings are more likely to live rebellious lives (see review, Nature 384, 125-126; 1996). The edition of Politics and the Life Sciences carrying the critiques $(19(2) ; 2000)$, which is not yet available online, had been delayed for four years by legal threats by Sulloway and associated problems.

Articles in the journal allege that Sulloway may have selected and manipulated data to prove his theories about how the order of birth of scientists and politicalleaders may have shaped their lives. "The evasiveness, the varying methodological accounts, the data discrepancies and the seemingly desperate attempts to interfere with publication together suggest that an independent review of Sulloway's research should be undertaken," says Johnson, who edited the journal for ten years until 2001, and then retained editorial responsibility for the edition on the Sullowaybook.

Sulloway, a former MacArthur Fellow and a visiting scholar at the Institute of Personality and Social Research at the University of California, Berkeley, strongly denies the allegations. He charges Johnson with "unprofessional editorial tactics" during the years of disagreement over the critical journal edition. In 2000, Sulloway even threatened to file a misconduct complaint of his own against Johnson with Robert Arbuckle, scholar at the Massachusetts Institute of Technology, Cambridge, when the book was published. Asked about the request to the NSF, Sulloway said he was unaware of it. "The only concern to me is the amount of time it takes to make all the data available," he says. "I'm just swamped with work."

Politics and the Life Sciences is published twice a year by the University of Maryland, having lost its publishing deal with Beech Tree Publishing of Guildford, UK, during the Sulloway disagreement.

The theories discussed in Born to Rebel about how birth order may influence personality have been hotly debated by psychologists for decades, and its high-profile publication reinvigorated that debate.

In late 1998, a critical analysis of it was submitted to Politics and the Life Sciences by Frederic Townsend, a Chicagobased commodity trader who had studied birth order in college. He alleged that Sulloway had selected data points to produce supportive figures, misused study results and manipulated personality characteristics of famous studied people. Townsend says he was surprised but delighted when peer reviewers - seven out of eight, in the end recommended publishing his 22-page article, which appeared with a 34-page editorial by Johnson. "An independent review of Sulloway's research is long overdue," Townsend says.

Sulloway says he never tried to halt the letter to Johnson in 1999 threatening legal action may have been too "strongly worded". He points to commentaries by scientific editors and friends who support his criticism of Johnson.

As is usual in such cases, the NSF declined to comment on the inquiry request. journal's publication, acknowledging that a
Germany's junior professors fight for their rights

Quirin Schiermeier, Munich

Guido Fischer has an identity problem. The 36-year-old microbiologist at the RWTH-Aachen University in Germany has no idea what to call himself. On his letterhead, he uses the bizarre Vorgriffsjuniorprofessor - which roughly translates as 'junior-professor-to-be'.

Fischer's dilemma is the result of a court ruling in July, which declared his chosen career path unconstitutional (see Nature 430, 599; 2004). His title of 'junior professor' was created in 2002 by a federal law that aimed to provide a fast-track to tenure for Germany's young scientists. But some of Germany's individual states, or Länder, took issue with the federal government's intrusion on the way they oversee science and education. Germany's highest court agreed that the federal government had no right to intrude, and some 600 young researchers were left unsure of their future.

At a meeting last week in Berlin, about 150 of these 'junior professors in limbo' called on federal and state science ministers to sort out the resulting mess.

Although initially employed under the same conditions, junior professors in different parts of Germany now have quite different rights and academic status. Those employed by universities in Berlin or Hanover, for example, can still call themselves professors, whereas their colleagues in Dresden or Aachen cannot.

The Förderverein Juniorprofessur a lobby group for the junior professors - last month drafted a proposal on how to restore equal status and improve career prospects. At last week's meeting, Edelgard Bulmahn, Germany's science minister, promised to include key points of their proposal in a revised federal university-education law, due to be introduced to the cabinet by the end of the month.

The Länder have indicated that they will not challenge the revised law, particularly as it now omits a promise to phase out the traditional method of obtaining tenure in Germany - a process called Habilitation that requires researchers to complete a second thesis. Some of the more conservative German Länder strongly opposed this change.

The revised law would reinstate the position of junior professorships, but critics say that the continued presence of Habilitation as a career option will make it difficult for junior professors to compete with other scientists for jobs. 